\title{
PEMBERDAYAAN EKONOMI IBU-IBU RUMAH TANGGA KECAMATAN PAKAL, KOTA SURABAYA
}

\author{
Yanuar Fauzuddin', Agung Bayu Murti², Karlin ${ }^{3}$, Andi Iswoyo ${ }^{4}$ \\ ${ }^{1}$ Universitas Wijaya Putra \\ ${ }^{2}$ Universitas Wijaya Putra \\ ${ }^{3}$ Universitas Wijaya Putra \\ ${ }^{4}$ Universitas Wijaya Putra
}

email yanuarfauzuddin@gmail.com, abayum@gmail.com, karlin354@gmail.com, andiiswoyo@gmail.com

\begin{abstract}
Abstrak
Daerah di Surabaya yang masih terdapat perempuan dalam kategori belum sejahtera adalah Kecamatan Pakal. Dari 6.595 keluarga, masih terdapat 74 keluarga yang belum sejahtera. Perbandingan ini terlihat sangat kecil, namun untuk Kota Surabaya hal ini menjadi permasalahan serius. Setiap tahun DP5A menyelenggarakan pemberdayaan perempuan, dan Kecamatan Pakal menjadi salah satu sasaran taun 2018. Pemberdayaan perempuan yang dilakukan bertujuan memberikan kemampuan membangun usaha produktif berbasis kemandirian. Kegiatan diselenggarakan atas kerjasama DP5A dengan Dosen FEB UWP serta Pakar dari TSI. Kegiatan dilakukan bulan April hingga Agustus 2018. Metode kegiatan yang digunakan adalah Pelatihan Produksi, Motivasi Usaha, Pelatihan Manajemen Usaha Sederhana, Penyuluhan Perijinan dan Permodalan serta Pendampingan dengan target mendapatkan omset usaha selama masa kegiatan pemberdayaan berlangsung. Hasil yang didapatkan dari kegiatan tersebut adalah peserta mampu 1). menghasilkan produk sesuai kualitas standar layak jual; 2) menghasilkan produk berkemasan layak jual pada segmen konsumen menengah; 3) mengimplementasikan materi pelatihan dan penyuluhan manajemen usaha, ditunjukkan dengan didapatkannya omset usaha. Capaian tersebut luar biasa mengingat peserta merupakan ibu-ibu rumah tangga tidak produktif dan belum memiliki keterampilan produksi serta pengalaman berwirausaha. Pemberdayaan masyarakat akan memberikan dampak yang sangat signifikan jika kegiatan yang dilakukan mencakup hulu hingga hilir, mulai dari pelatihan, bantuan modal hingga pendampingan serta pengawasan berkelanjutan.
\end{abstract}

Kata Kunci : Pemberdayaan, Perempuan, Kewirausahaan, Mandiri, Surabaya

\section{PENDAHULUAN}

Kemiskinan dan kesejahteraan menjadi permasalahan klasik setiap negara, tidak terlepas Indonesia. Tingkat kemiskinan nasional di Indonesia sebesar 9,66\% (Badan Pusat Statistik, 2019). Setiap tahunnya, Pemerintah Indonesia mengalokasikan anggaran dan program-program pengentasan kemiskinan serta peningkatan kesejahteraan rakyat. Permasalahan kemiskinan dan kesejahteraan di Indonesia tidak hanya muncul pada daerah-daerah Kabupaten yang identik dengan daerah Desa-nya, namun juga masih terjadi di daerah perkotaan. Salah satu kota di Indonesia yang telah dikenal sebagai kota metropolitan, yaitu Surabaya, hingga kini masih menghadapi permasalahan kemiskinan dan kesejahteraan. 
Daerah di Surabaya yang masih terdapat perempuan dalam kategori belum sejahtera adalah Kecamatan Pakal. Dari 6.595 keluarga, masih terdapat 74 keluarga yang belum sejahtera (BPS Kota Surabaya, 2019). Perbandingan ini terlihat sangat kecil, namun untuk Kota Surabaya hal ini menjadi permasalahan serius, mengingat status kotanya sebagai kota metropolitan.

Bagi pemerintah, kegagalan penyelenggaraan pemerintahan adalah ketika masih memiliki masyarakat yang berada pada kemiskinan dan ketidaksejahteraan. Pemerintah Kota Surabaya memiliki perangkat-perangkat kedinasan yang diberi tanggung jawab untuk mengentaskan kemiskinan dan meningkatkan kesejahteraan masyarakatnya, antara lain Dinas Pengendalian Penduduk, Pemberdayaan Perempuan dan Perlindungan Anak (DP5A). Salah satu tugas pokok DP5A adalah memberdayakan perempuanperempuan secara ekonomi dalam rangka meningkatkan taraf hidup perempuan.

Setiap tahun DP5A menyelenggarakan pemberdayaan perempuan, dan Kecamatan Pakal menjadi salah satu sasaran pada taun 2018. Pemberdayaan perempuan yang dilakukan bertujuan memberikan kemampuan membangun usaha produktif berbasis kemandirian. Kegiatan diselenggarakan atas kerjasama DP5A dengan Dosen Fakultas Ekonomi dan Bisnis Universitas Wijaya Putra Surabaya (FEB UWP) serta Pakar dari PT. Talenta Sukses Indonesia (TSI). Kegiatan ini dilakukan pada bulan April hingga Agustus 2018.

Permasalahan yang dihadapi oleh DP5A setiap kali menyelenggarakan program pemberdayaan ekonomi perempuan adalah tingkat partisipasi yang rendah dari peserta yang ditunjuk, serta kurang positifnya dampak yang diberikan oleh program. Tingkat partisipasi yang rendah dilihat dari perkembangan keikutsertaan peserta dalam setiap satu kurun waktu kegiatan, dimana hanya pada awal kegiatan saja, peserta berpartisipasi aktif, namun menjelang pertengahan dan akhir kegiatan, peserta yang masih terlibat aktif tidak lebih dari 25\%. Dampak program yang kurang positif seringkali disebabkan karena program dilaksanakan secara parsial, yaitu hanya memberikan pelatihan keterampilan atau pelatihan manajemen usaha atau bantuan modal saja.

Dalam lingkup efektifitas dan efisiensi, penyelenggaraan program secara parsial kurang memberikan dampak positif langsung terhadap peserta. Penyelenggaraan program pelatihan keterampilan saja tidak mengarahkan peserta program untuk mempraktekkannya untuk usaha produksi, karena tidak dilakukan pendampingan pasca pelatihan dan kurangnya modal untuk memulai usaha. Penyelenggaraan program pelatihan manajemen usaha saja tidak berpengaruh terhadap inisiasi dalam memulai wirausaha, karena peserta minim keterampilan produksi dan modal usaha. Penyelenggaraan program bantuan modal usaha saja juga tidak mampu menggerakkan peserta untuk memulai produksi dan usaha, karena tidak ada kemampuan dalam mengelola usaha mandiri. Justru seringkali bantuan modal usaha disalahgunakan untuk hal lainnya. Jika diberikan bantuan modal berupa uang, maka seringkali uang tersebut digunakan untuk membayar hutang, dan jika bantuan modal usaha yang diberikan berupa peralatan produksi, seringkali alat produksi tersebut dijual kembali sehingga menghasilkan uang, yang mana uang tersebut digunakan untuk kebutuhan sehari-hari atau membayar hutang.

Dari permasalahan-permasalahan ini, tim Dosen dari FEB UWP dan Pakar dari TSI, memberikan sentuhan-sentuhan praktis dalam rangka membantu keberhasilan program pemberdayaan ekonomi perempuan dari DP5A. Sentuhan-sentuhan praktis tersebut diwujudkan dalam bentuk metode dan implementasi pemberdayaan ekonomi secara komprehensif, dengan perlakuan dari hulu hingga hilir, yaitu mulai dari program pemberian motivasi, pelatihan ketrampilan, pelatihan manajemen usaha, penyuluhan perijinan dan permodalan, pendampingan usaha hingga bantuan modal peralatan usaha. Secara kebijakan, saat ini Pemerintah Kota Surabaya menghentikan program bantuan modal usaha bagi peserta pemberdayaan, dikarenakan pengalaman-pengalaman terdahulu, dimana bantuan tersebut banyak disalahgunakan. Oleh karenanya sentuhan bantuan modal usaha pada program kali ini dirupakan dalam bentuk penghargaan prestasi partisipasi peserta program.

Dengan inovasi perlakuan dalam program pemberdayaan ekonomi perempuan ini diharapkan dapat membantu keberhasilan program pemberdayaan dari Pemerintah Kota Surabaya serta secara khusus dapat meningkatkan kesejahteraan ekonomi keluarga miskin di Surabaya melalui Ekonomi, Sosial, dan Budaya

1231 
peserta sasaran. Peserta sasaran dalam program pemberdayaan ini adalah ibu-ibu rumah tangga Kecamatan Pakal, Surabaya, yang memiliki tingkat ekonomi rendah.

\section{METODE}

Kegiatan ini dilakukan dengan metode pemberdayaan masyarakat, yaitu penyuluhan teknis dan motivasi, pelatihan keterampilan produksi, pelatihan manajemen usaha serta pendampingan usaha dan bantuan modal peralatan produksi. Dengan metode ini maka kegiatan akan mencakup keseluruhan usaha mulai dari hulu hingga hilir, sehingga apa yang telah diusahakan dapat memberikan hasil yang nyata (Arif dan Fauzuddin, 2017). Secara umum, permasalahan yang dihadapi mitra adalah kondisi ekonomi yang masih di bawah rata-rata dan tingkat produktivitas yang masih rendah. Untuk mengatasi permasalahan tersebut, tim penyelenggara dan pelaksana memberikan solusi berupa membangun lapangan usaha produktif. Sasaran kegiatan ini adalah ibu-ibu rumah tangga di Kecamatan Pakal Surabaya dengan tujuan meningkatkan produktivitas ekonomi keluarga, yang mana pada awalnya kegiatan ibu-ibu rumah tangga ini hanya melakukan pekerjan rumah tangga, maka kini diarahkan untuk memiliki kegiatan yang dapat menghasilkan pendapatan finansial. Dari hal tersebut maka ditentukanlah kegiatan yang mampu meningkatkan produktivitas ekonomi yang mempertimbangkan keterbatasan kemampuan masyarakat dan jenis produksi yang memungkinkan untuk dilakukan masyarakat sasaran. Penentuan jenis usaha dan produksi menggunakan prinsip Mudah, Murah dan Cepat Menghasilkan. "Mudah", yaitu produk yang diproduksi sangat mudah untuk dibuat, tanpa mengharuskan keahlian khusus, serta peralatan dan perlengkapan yang digunakan mudah didapat dan sudah sering digunakan sehari-harinya. "Murah", produk yang diproduksi tidak membutuhkan modal finansial yang besar dan mampu dijangkau masyarakat sasaran. "Cepat Menghasilkan", produk yang diproduksi harus memiliki daya jual yang cepat. Dari prinsip-prinsip tersebut, ditentukan produk yang akan dijadikan produk usaha adalah makanan ringan "Kembang Goyang". Guna mengatasi permasalahan-permasalahan yang ada dilakukan dengan metode yang diuraikan berikut ini.

\section{Penyuluhan Teknis dan Motivasi}

Penyuluhan teknis dan motivasi yang dilakukan antara lain:

a. Sosialisasi Teknis

Sosialisasi teknis diberikan dalam rangka menjelaskan kepada peserta mengenai teknis pelaksanaan serta tujuan program yang dilakukan.

b. Penyuluhan Motivasi Memulai Wirausaha, Motivasi Mental Blocking, dan Motivasi Pengembangan Usaha.

Penyuluhan motivasi secara formal tidak hanya dilakukan pada awal pelaksanaan kegiatan namun dilakukan pada awal, pertengahan dan akhir pelaksanaan kegiatan. Hal ini bertujuan untuk menumbuhkan motivasi pada awal memulai kegiatan, mempertahankan dan mengendalikan motivasi yang cenderung menurun selama mengikuti rangkaian kegiatan dan meningkatkan motivasi dalam rangka mempersiapkan diri untuk menjalankan usaha pasca program. Namun secara informal, motivasi usaha terus ditanamkan selama pertemuan kegiatan.

c. Penyuluhan Perijinan Usaha

Penyuluhan perijinan usaha diberikan untuk memberikan wawasan pentingnya ijin usaha dan tata cara mendapatkan perijinan usaha.

d. Penyuluhan Permodalan Usaha

Penyuluhan permodalan usaha diberikan untuk memberikan wawasan jalur-jalur dalam mendapatkan sumber permodalan usaha mikro dan kecil.

\section{Pelatihan Keterampilan Produksi dan Manajemen Usaha}

Pelatihan keterampilan dan motivasi yang dilakukan antara lain:

a. Pelatihan Keterampilan Produksi "Kembang Goyang"

Pelatihan membuat produk "Kembang Goyang" tidak hanya mengajarkan bagaimana cara membuatnya, namun juga memberikan tips dan 
trik mengenai menghasilkan dan mengendalikan mutu produk yang layak jual pada konsumen segmen menengah keatas.

b. Pelatihan Manajemen Pemasaran dan Tata Rupa Pelatihan manajemen pemasaran dan tata rupa memberikan teknik-teknik pemasaran secara offline dan online, mulai dari media pemasaran, teknik komunikasi penawaran dan penjualan hingga teknik mempertahankan pelanggan yang potensial.

c. Pelatihan Manajemen Keuangan dan Pembukuan Pelatihan manajemen keuangan dan pembukuan memberikan teknik pengelolaan modal yang minim dan omset usaha yang berorientasi pada pengembangan usaha berkelanjutan dan juga memberikan teknik-teknik pencatatan keuangan usaha mikro dan kecil.

d. Pelatihan Organisasi dan SDM

Pelatihan organisasi dan SDM memberikan teknik-teknik dalam memulai membangun organisasi serta pengelolaan SDM usaha mikro.

\section{Pendampingan Usaha}

Pendampingan usaha dilakukan dengan cara bertemu secara rutin dan kunjungan lapangan tempat usaha, dalam rangka:

a. Memastikan penerapan hasil penyuluhan dan pelatihan yang telah diberikan, mulai dari mutu produk, teknik pemasaran dan tata rupa, pembukuan keuangan usaha dan pengelolaan organisasi usaha hingga proses perijinan;

b. Mengidentifikasi dan memberikan saran solutif mengenai permasalahan-permasalahan yang dihadapi; dan

c. Memonitor perkembangan pencapaian omset usaha.

\section{Bantuan Modal Peralatan Produksi}

Bantuan modal peralatan produksi tidak diberikan secara langsung pada awal pelaksanaan kegiatan. Hal ini untuk menghindari kecenderungan peserta program yang seringkali ketika telah diberikan bantuan modal diawal kegiatan tidak lagi berpartisipasi pada rangkaian-rangkaian kegiatan selanjutnya. Bantuan modal juga tidak diberikan dalam bentuk finansial, karena menghindari kecenderungan penyalahgunaan bantuan finansial yang diberikan untuk hal-hal lain yang tidak terkait tujuan kegiatan. Bantuan modal yang diberikan juga tidak diperuntukkan bagi seluruh peserta, namun dirancang sebagai bentuk penghargaan bagi peserta yang berhasil menghasilkan omset usaha terbesar pada akhir kegiatan. Hal ini dilakukan untuk menumbuhkan dan mempertahankan motivasi peserta selama mengikuti program pemberdayaan.

\section{HASIL DAN PEMBAHASAN}

Program kegiatan pemberdayaan masyarakat ini dilaksanakan selama kurang lebih lima bulan, dimulai dari bulan April hingga Agustus 2018. Secara ringkas, skema tahapan kegiatan yang dilakukan digambarkan pada flowchart di bawah ini.

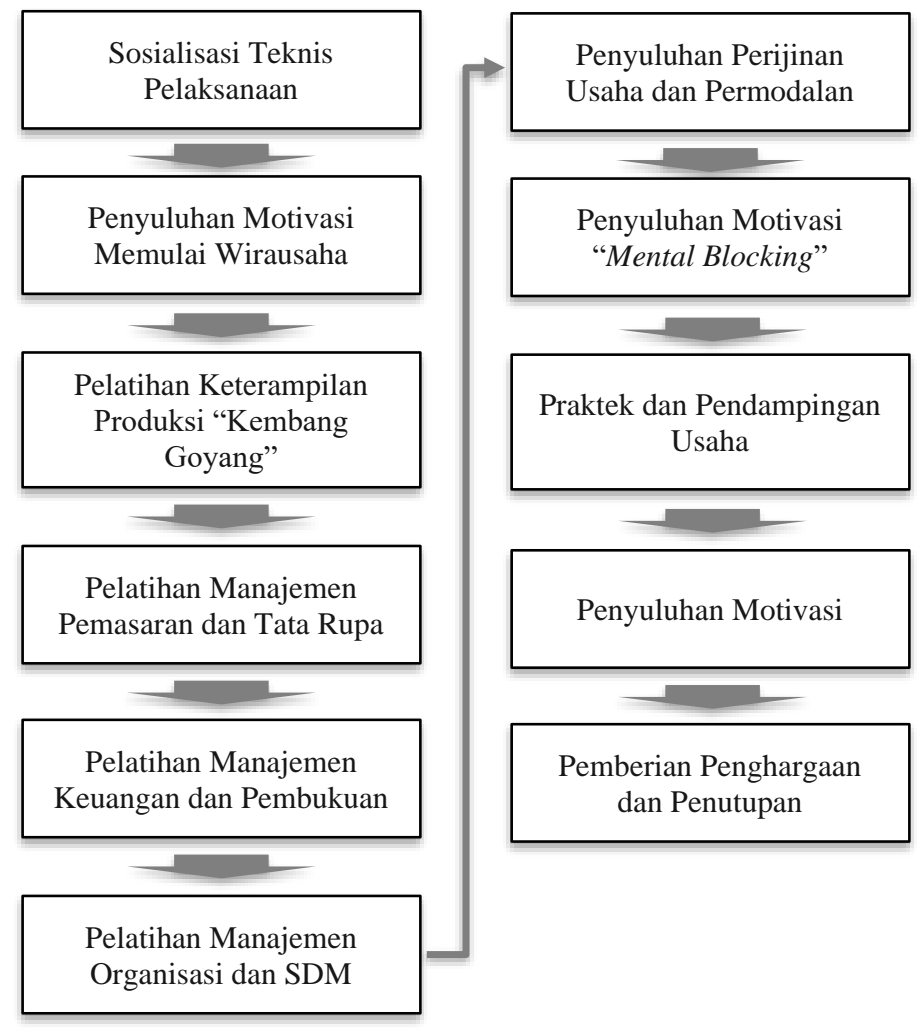

Gambar 1. Skema Tahapan Kegiatan

Dalam program kegiatan ini, peserta tidak diberikan modal usaha, baik secara finansial maupun peralatan dan perlengkapan produksi. Bantuan peralatan produksi hanya diberikan pada akhir pelaksanaan program sebagai penghargaan kepada peserta yang mencapai omset tertinggi. Data awal yang ditentukan oleh DP5A Pemkot Surabaya, terdapat 74 peserta, namun setelah dilakukan survei pendahuluan, hanya 30 peserta yang mengikuti

$$
\text { Ekonomi, Sosial, dan Budaya }
$$


program kegiatan ini. Ketidakikutsertaan 44 peserta lainnya dikarenakan antara lain telah berpindah domisili di daerah lain atau telah mendapatkan pekerjaan. Dari 30 peserta ini, yang mengikuti hingga tahapan terakhir sejumlah 20 orang. Jumlah ini terhitung sangat luar biasa, mengingat program kegiatan pemberdayaan dilakukan tanpa memberikan bantuan modal dimana bertolak belakang dengan tujuan yang menuntut peserta untuk berproduksi serta melakukan pemasaran dan penjualan hingga menghasilkan omset. Selain itu mengingat peserta sasaran adalah ibu-ibu rumah tangga dari keluarga dengan tingkat ekonomi rendah, yang sudah tentu dari sisi finansial akan memiliki pertimbangan besar dalam mengalokasikan dana guna mengawali usaha. Kebutuhan akan sebuah pencapaian menjadi salah satu faktor kritis dalam mengukur tingkat motivasi seseorang (Setyaningsih dkk, 2012).

Perlakukan khusus yang diberikan kepada peserta agar memiliki minat dan daya usaha yang tinggi selama jalannya program kegiatan adalah melalui pemberian motivasi yang berkelanjutan dan intensif. Perlakukan motivasi tidak hanya diberikan pada tahapan-tahapan yang ditunjukkan di skema tahapan kegiatan, namun dalam setiap pertemuan melalui materi yang disampaikan dan di luar pertemuan melalui sebuah grup media sosial percakapan (Whatsapp). Selain itu, melibatkan narasumber keterampilan produksi dengan kualifikasi memiliki kesuksesan pengalaman merintis usaha dari modal yang minim (bahkan dalam kondisi ekonomi banyak hutang) hingga kini berhasil dalam skala nasional sekaligus ahli dalam memproduksi "kembang goyang", menjadi salah satu cara yang berpengaruh positif terhadap motivasi peserta, melalui testimoni-testimoni yang diungkapkan dan kepedulian narasumber tersebut selama memberikan keterampilan produksi "kembang goyang".

Kebutuhan perlakuan khusus motivasi peserta ini juga diorganisir dengan dibentuk struktur organisasi tim yang memampukan monitoring terhadap perkembangan peserta. Hal ini dilakukan untuk memberikan tanggapan yang responsif selama jalannya program kegiatan ketika terjadi indikasi penurunan motivasi peserta maupun pertanyaan-pertanyaan peserta di luar pertemuan yang membutuhkan jawaban dari narasumber teknis terkait. Struktur organisasi yang digunakan sebagai berikut.

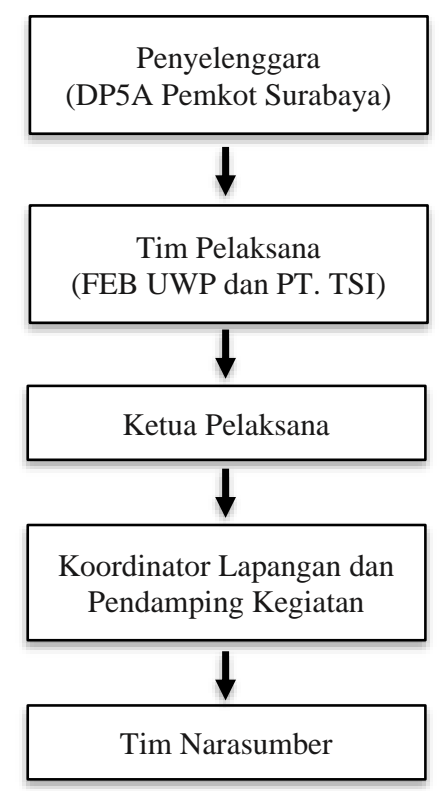

Gambar 2. Struktur Organisasi Tim

Pada dasarnya, ketika yang menjadi peserta sasaran program pemberdayaan adalah masyarakat dengan tingkat ekonomi rendah, mayoritas yang mereka butuhkan adalah perhatian personal dari seseorang yang mereka nilai memiliki kemampuan dalam melakukan sesuatu dan membuktikan hasilnya. Oleh karenanya, tim pelaksana beserta tim narasumber, selain memberikan materi teknis, juga mengoptimalkan kemampuan interpersonalnya untuk berkomunikasi dengan peserta, baik dalam setiap pertemuan maupun di luar pertemuan pada kurun waktu pelaksanaan program. Keterikatan kewirausahaan membutuhkan lebih dari sekedar modal dan ide, yaitu perlakuan personal (Ismail, dkk, 2016).

Perlakuan-perlakuan khusus ini menghasilkan pengaruh positif yang sangat signifikan, melihat dari penurunan jumlah peserta selama 5 bulan pelaksanaan (dipertengahan jadwal pelaksanaan terdapat masa libur hari raya) tidak kurang dari $60 \%$. Rasio ini tidak pernah dicapai oleh DP5A selama menyelenggarakan program pemberdayaan ekonomi perempuan.

Ekonomi, Sosial, dan Budaya

1234 

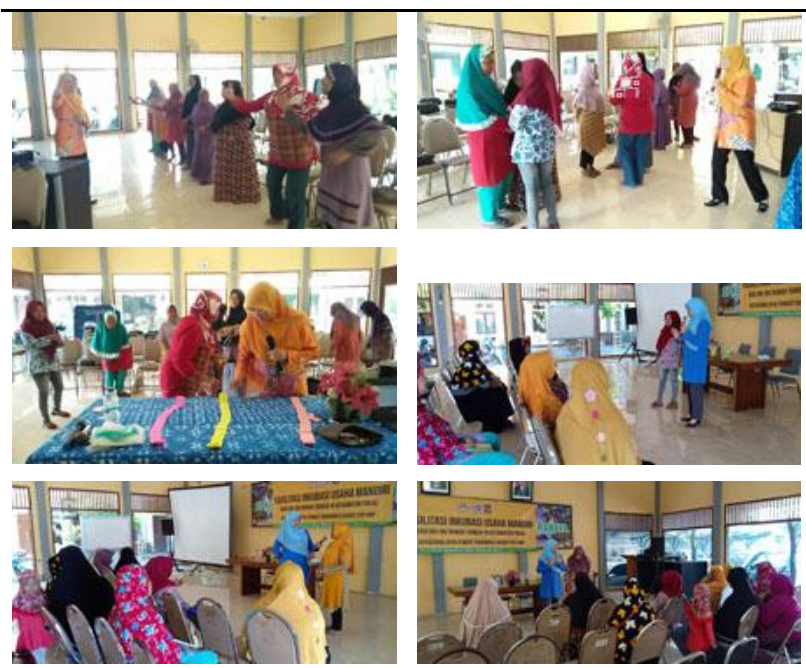

Gambar 3. Pemberian Materi Motivasi Usaha

Hasil teknis pelaksanaan program kegiatan pemberdayaan yang dilakukan, diuraikan sebagai berikut.

\section{Keterampilan Produksi}

90\% peserta program tidak bisa dan tidak pernah membuat produk "kembang goyang" sebelumnya. Pemberian pelatihan keterampilan membuat makanan "kembang goyang" dilakukan satu kali. Karena bahan-bahan dan peralatan yang digunakan sudah familiar dan digunakan seharihari, serta cara mengolah bahan dan proses memasaknya sangat mudah, maka peserta cepat menguasainya. Pelatihan dilakukan secara praktek dengan menekankan pada tips dan trik, mulai dari cara memilih bahan, cara menggunakan peralatan, cara perlakuan adonan, cara memasak hingga cara penirisan dan penyimpanan. Hal ini dilakukan secara standar untuk menghasilkan mutu yang layak jual dan dapat diterima oleh calon konsumen pada segmen menengah keatas. Seperti contoh, tidak boleh menggunakan kertas bekas pakai (kertas koran, kertas hasil cetak print, dokumen-dokumen bekas, dll), namun harus memakai kertas merang, karena secara kehigienisan, kertas bekas pakai memberikan peluang mencemari makanan yang ditiriskan melalui tinta yang terdapat di kertas tersebut. Selain itu penggunaan kertas merang dikarenakan kertas ini memang khusus digunakan untuk menyerap sisa minyak dari makanan hasil penggorengan.

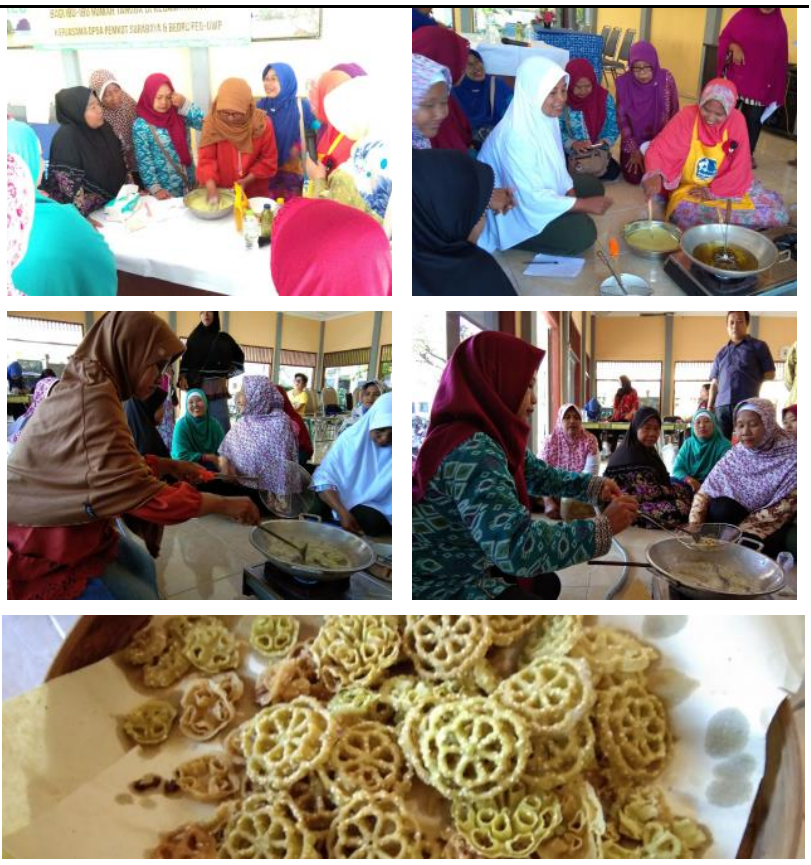

Gambar 4. Pelatihan Keterampilan Produksi "Kembang Goyang"

Setelah mengikuti pelatihan keterampilan, peserta diarahkan untuk melakukan praktek di rumah masing-masing secara mandiri. Hasil yang didapat dari praktek secara mandiri ini akan di bawa pada pertemuan-pertemuan berikutnya untuk dievaluasi kelayakan rasa, rupa dan tekstur dalam rangka standar layak jual. Pada awal melakukan praktek sendiri, masih banyak peserta yang kelayakan rasa, tekstur dan rupa masih di bawah standar layak jual. Evaluasi yang dilakukan dalam rangka mengarahkan pola pikir peserta yang mana standar layak jualnya masih pada segmen konsumen menengah kebawah, sehingga gambaran yang dibayangkan adalah untuk dijual di warung-warung kopi dan toko-toko kecil. Prinsip arahan yang diberikan kepada peserta adalah walaupun dengan modal yang minimal tetapi harus mampu menyajikan produk yang optimal, karena nilai jualnya akan tinggi dan tingkat pengembalian modalnya juga akan tinggi.

Beberapa permasalahan hasil produksi yang dihadapi antara lain rasa yang "apek"; tekstur yang keras (tidak "krenyes") dan berminyak; serta warna yang kusam atau terlalu mencolok. Setelah dievaluasi ternyata terdapat beberapa standar kritis yang tidak dilakukan, yaitu penggunaan bahanbahan yang sudah lama, komposisi bahan yang 
tidak presisi, serta penggunaan pewarna yang tidak tepat. Hasil produksi awal yang ditunjukkan oleh peserta ditunjukkan pada gambar di bawah ini.

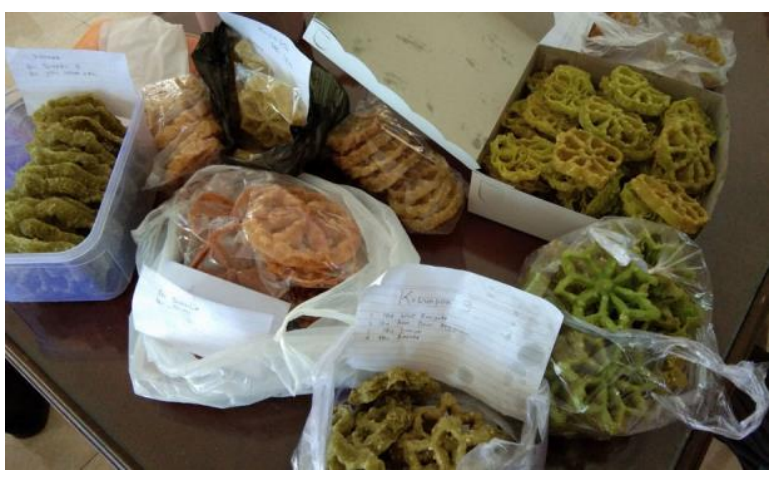

Gambar 5. Hasil Awal Praktek Mandiri Peserta

Dengan melakukan evaluasi pada beberapa kali pertemuan, peserta mulai menunjukkan perubahan kualitas kemampuan produksi, mulai dari rasa yang enak, tekstur yang "krenyes" dan warna yang menarik (tidak kusam dan tidak terlalu mencolok). Selain itu juga produk yang dihasilkan telah dikemas secara bagus seperti ditampilkan pada gambar di bawah ini.

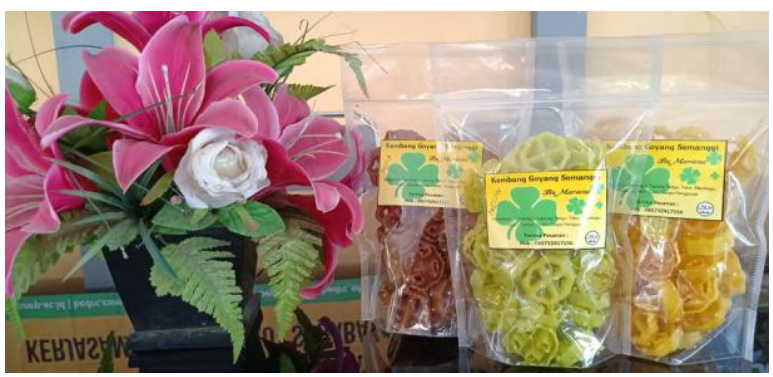

Gambar 6. Hasil Akhir Praktek Mandiri Peserta

\section{Kemampuan Manajemen Usaha}

Kemampuan manajemen usaha para peserta tentunya sangat minim, dan bahkan tidak memilikinya, karena peserta sasaran merupak ibuibu rumah tangga mayoritas tidak pernah menjalankan usaha mandiri. Pembekalan dan pendampingan mulai teknik pemasaran, pengelolaan keuangan dan teknik pembukuan serta pengelolaan organisasi dan SDM mikro kecil hingga tata cara perijinan usaha dan permodalan usaha mikro kecil diberikan secara bertahap.
Materi kritis yang diberikan tentang pengelolaan keuangan adalah mengenai bagaimana mengendalikan diri dalam mengelola dana pribadi dan dana usaha. Hal ini berpengaruh dalam pembukuan keuangan usaha dan pengembangan usaha secara berkelanjutan. Seringkali modal usaha dan pendapatan usaha disimpan menjadi satu dengan dana pribadi, sehingga penggunaan dan perhitungannya menjadi tidak terkendali. Solusi yang diberikan adalah memisahkan keuangan usaha dengan keuangan pribadi, sehingga keuangan usaha dapat dikendalikan dan dievaluasi perkembangannya. Pembukuan keuangan usaha dilakukan secara sederhana.

Materi kritis pada pengelolaan organisasi dan SDM usaha mikro kecil dititikberatkan pada cara peserta mengelola pola kegiatan sehari-harinya. Hal ini diberikan mengingat sebelum mengikuti program kegiatan pemberdayaan ini, para peserta sudah terbiasa dengan pola kegiatan rumah tangga yang meliputi memasak, membersihkan rumah, mengantar anak sekolah, dan lain-lain. Dengan mengikuti program kegiatan pemberdayaan ini, peserta diarahkan untuk mampu melakukan usaha mandiri, yang tentunya akan mengganggu rutinitas sebelumnya. Namun dengan pemahaman dan pendekatan personal yang dilakukan tidak hanya pada pertemuan inti, namun juga pada saat pendampingan, peserta akhirnya mampu mengelola rutinitas barunya, yaitu sebagai ibu rumah tangga dan sebagai pengusaha.

Materi penyuluhan permodalan hanya difokuskan pada wawasan tentang jalur-jalur perolehan modal kredit. Peserta tidak diarahkan untuk melakukan pinjaman pada lembaga-lembaga penyalur kredit usaha, karena hal ini akan memberatkan peserta yang masih berada dalam tahap awal merintis usaha. Selain itu dalam materi ini peserta selalu diingatkan untuk mengoptimalkan terlebih dahulu modal yang dimiliki hingga saatnya melakukan pengembangan usaha. Dan juga peserta selalu diingatkan untuk menghindari rentenir, yaitu pemberi pinjaman yang tidak terdaftar pada Otoritas Jasa Keuangan (OJK). Materi perijinan usaha mengarahkan peserta untuk minimal mampu mengurus Surat Keterangan Domisili Usaha (SKDU) di tingkat kelurahan serta mengikuti penyuluhan produk makanan dari Dinas Kesehatan 
sebagai bekal pengurusan PIRT (Pangan Industri Rumah Tangga) yang difasilitasi oleh pihak DP5A.

Fokus utama pada materi manajemen usaha secara keseluruhan adalah tentang manajemen pemasaran. Hal ini dikarenakan peserta harus mampu menghasilkan omset dalam kurun waktu pelaksanaan program kegiatan pemberdayaan ini. Tuntutan ini untuk memberikan stimulus antusias peserta dalam memulai usaha. Peserta yang dapat merasakan hasil kegiatan berupa pendapatan usaha akan mendapatkan kepuasan karena merasakan secara langsung bahwa pengorbanan yang dilakukan tidak sia-sia dan memberikan hasil nyata. Inilah mengapa produk yang dipilih adalah produk yang "Mudah" dibuat, "Murah" dalam bahan dan alatnya serta "Cepat Menghasilkan" ketika dijual, sehingga dimungkinkan dalam kurun waktu lima bulan, peserta mampu melakukan produksi sesuai standar dan menjualnya hingga menghasilkan pendapatan.

Materi yang diberikan adalah pemasaran offline dan online. Pemasaran online telah menjadi tren kekinian dalam perniagaan saat ini. Materi pemasaran online ini juga didukung dengan mobilitas peserta yang sudah menggunakan smartphone dalam berkomunikasi. Secara luas, teknologi informasi dan komunikasi merupakan kunci solutif dalam pengembangan secara komprehensif, pengentasan kemiskinan dan pemberdayaan kelompok-kelompok bawah (Victoria, 2019). Materi yang diberikan adalah optimasi penggunaan perangkat smartphone dan media-media sosial untuk pemasaran dan penjualan produk. Pemasaran dan penjualan tentunya tidak dapat menggantungkan dari teknik online saja, namun juga tetap menggunakan metode konvensional secara offline, yaitu mengenai penentuan segmen dan target konsumen, direct promotion hingga pemaketan produk (product bundling).

Dalam keseluruhan materi pemasaran, yang menjadi pokok materi adalah cara komunikasi pemasaran dan penjualan, yaitu bagaimana peserta melakukan komunikasi awal dengan calon konsumen hingga mengarahkan pada "dealing" transaksi. Materi ini sangat berpengaruh pada tahap awal praktek pemasaran dan penjualan yang dilakukan peserta. Peserta merasa takut atau malu saat mengawali komunikasi dengan calon konsumen, namun setelah merasakan keberhasilannya, para peserta merasa "ketagihan" untuk terus melakukannya. Hingga pada akhirnya dari beberapa peserta mampu menjaring konsumen yang berasal dari luar Surabaya.

Materi-materi manajemen usaha ini tidak hanya diberikan secara tatap muka di kelas, namun juga melalui pendampingan-pendampingan dan kunjungan langsung ke lokasi usaha (dalam hal ini masing-masing rumah peserta).
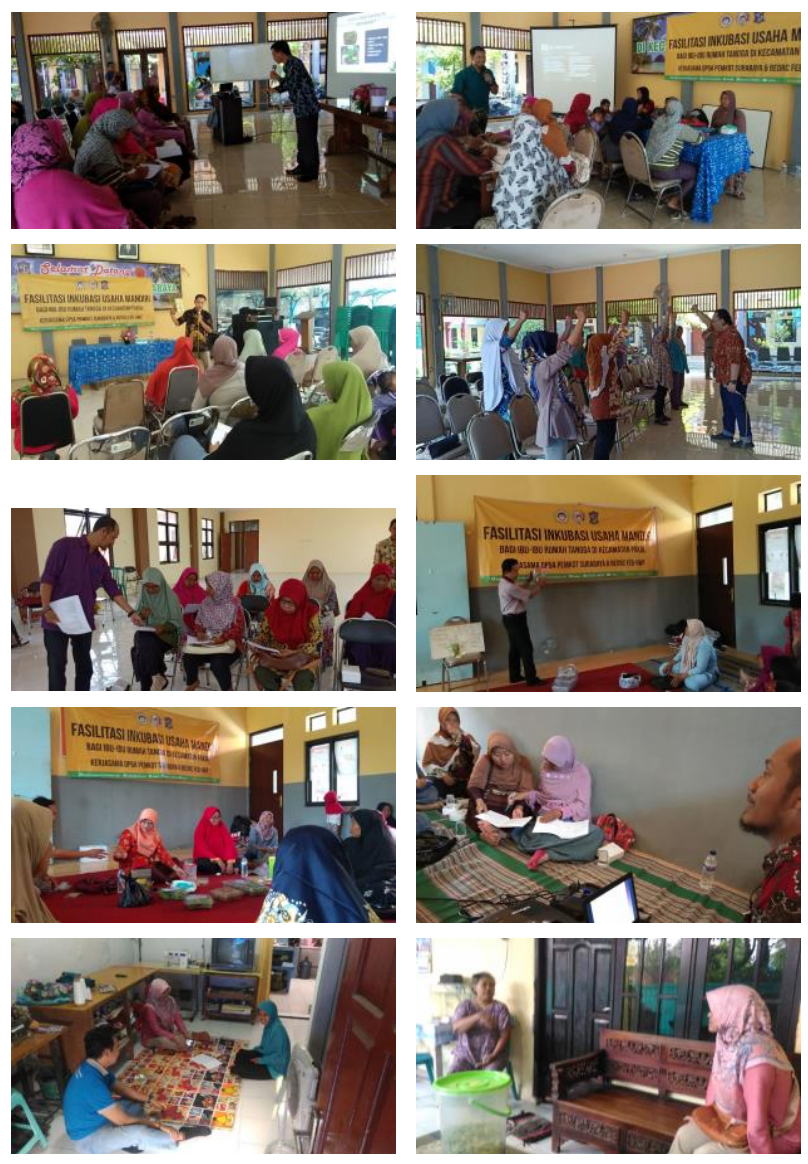

Gambar 7. Pelaksanaan Pelatihan dan

Pendmapingan Manajemen Usaha

\section{Pencapaian Target Omset}

Pelaksanaan praktek pemasaran dan penjualan yang dilakukan peserta secara jadwal adalah pada bulan kedua, yaitu setelah pemberian materi sosialisasi, keterampilan produksi, pemasaran dan keuangan. Namun hal ini bersifat tentatif, yaitu menyesuaikan kesiapan produk peserta dan keberanian peserta dalam mengawali praktek. Secara efektif keseluruhan, peserta baru mulai menjalankan praktek pemasaran dan

$$
\text { Ekonomi, Sosial, dan Budaya }
$$


penjualan pada ketiga dengan hasil omset yang ditunjukkan pada tabel di bawah ini.

Tabel 1. Total Omset Peserta Program

Pemberdayaan Pada Akhir Bulan Kelima

\begin{tabular}{cc}
\hline & Total Omset Bulan 5 \\
\cline { 2 - 2 } Peserta & $($ Rp. $)$ \\
\hline $\mathbf{2}$ & 0 \\
3 & $\mathbf{6 . 1 7 0 . 0 0 0}$ \\
4 & 3.450 .000 \\
$\mathbf{5}$ & 0 \\
6 & $\mathbf{5 . 8 3 5 . 0 0 0}$ \\
7 & 5.310 .000 \\
8 & 1.355 .000 \\
9 & 2.775 .000 \\
10 & 0 \\
$\mathbf{1 1}$ & 1.150 .000 \\
12 & $\mathbf{5 . 9 5 0 . 0 0 0}$ \\
13 & 3.085 .000 \\
14 & 1.665 .000 \\
15 & 1.880 .00 \\
16 & 1.175 .000 \\
17 & 4.560 .000 \\
18 & 0 \\
19 & 1.225 .000 \\
20 & 1.500 .000 \\
\hline
\end{tabular}

Dari data total perolehan omset peserta diatas, dapat dilihat bahwa terdapat 5 peserta yang tidak menghasilkan omset usaha sama sekali. Hal ini dikarenakan kelima peserta tersebut ada yang memang tidak berorientasi untuk memulai usaha dan berusia lanjut (diatas 60 tahun). Namun secara mayoritas keseluruhan peserta mampu menghasilkan total omset diatas satu juta rupiah dalam kurun waktu tiga bulan efektif. Hal ini menjadi pencapaian yang luar biasa, mengingat para peserta merupakan ibu-ibu rumah tangga tidak produktif, yang belum pernah memproduksi makanan dengan standar layak jual (khususnya "kembang goyang") dan belum pernah menjalankan usaha mandiri.

Tiga peserta dengan capaian omset tertinggi mendapatkan penghargaan berupa bantuan perlatan produksi utama, sedangkan lainnya yang juga menghasilkan omset mendapatkan penghargaan berupa peralatan produksi penunjang. Penghargaan ini sebagai bentuk apresiasi atas usaha dan pengorbanan yang telah dilakukan, serta sebagai bentuk bantuan yang langsung berdampak pada kegunaan produksi.
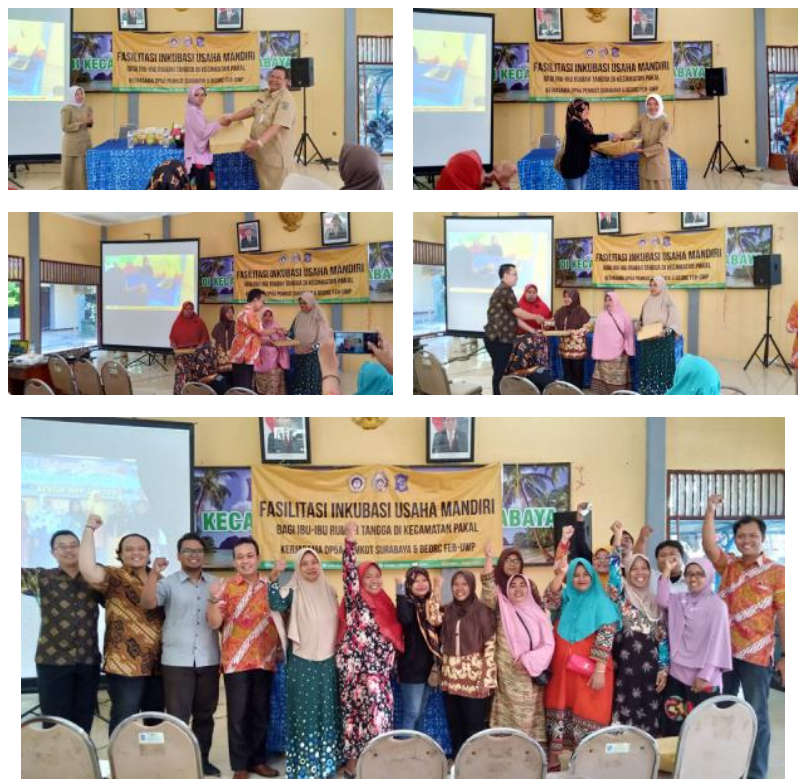

Gambar 8. Pemberian Penghargaan dan Penutupan Program Kegiatan Pemberdayaan

\section{KESIMPULAN}

Pemberdayaan masyarakat akan memberikan dampak yang sangat signifikan jika kegiatan yang dilakukan mencakup hulu hingga hilir, mulai dari pelatihan, bantuan modal dan pendampingan serta pengawasan berkelanjutan. Program kewirausahaan melalui kegiatan pemberdayaan dengan karakteristik peserta tidak produktif dan tingkat ekonomi rendah membutuhkan pemberian materi motivasi yang intensif, baik ketika di ruang kelas maupun pendampingan dan di luar pertemuan formal. Produk yang memiliki kemudahan dan biaya yang murah dalam proses produksi membuat peserta senantiasa aktif dalam praktek produksi mandiri dan memudahkan peserta dalam memulai usaha produksi. Produk dengan karakteristik cepat diproduksi dan cepat menghasilkan dapat

$$
\text { Ekonomi, Sosial, dan Budaya }
$$


meningkatkan antusiasme peserta dalam memulai wirausaha, karena perputaran uang cepat dapat memberikan kepuasan dalam berusaha yang berpengaruh pada tingkat motivasi peserta. Materi kritis pada lingkup manajemen usaha ada pada pemasaran. Dengan memberikan pengetahuan dan keterampilan yang praktis serta pendampingan yang intensif, akan membuat peserta semangat dalam mempraktekkannya secara berkelanjutan. Hal ini dikarenakan materi teknik pemasaran praktis dan pendampingan intensif ini dapat secara nyata memberikan dampak positif berupa didapatkannya hasil penjualan. Hasil penjualan inilah yang membuat peserta merasa bangga terhadap capaian usahanya yang nyata dan merasa penasaran untuk meningkatkan kemampuan dalam menghasilkan pendapatan melalui usaha mandiri.

\section{UCAPAN TERIMAKASIH}

disampaikan kepada:

Terima kasih yang sebesar-besarnya

1. Dinas Pengendalian Penduduk, Pemberdayaan Perempuan dan Perlindungan Anak, Pemerintah Kota Surabaya;

2. Kecamatan Pakal Surabaya;

3. Universitas Wijaya Putra Surabaya;

4. PT. Talenta Sukses Indonesia.

\section{REFERENSI}

Arif, M. S., \& Yanuar F. (2017). IPTEKS

Bagi Masyarakat (IBM) Kelompok Ibu-Ibu Rumah
Tangga Desa Banjarejo Kecamatan Ngadiluwih Kabupaten Kediri. Asian Journal of Innovation and Entrepreneurship, 02 (01): 25-35.

Badan Pusat Statistik Kota Surabaya (2019). Kecamatan Pakal Dalam Angka 2018.

Badan Pusat Statistik. (2019). Profil Kemiskinan di Indonesia September 2018. Nomor 07/01/Thn XXII. Diakses 6 Agustus 2019. https://www.bps.go.id/pressrelease/2019/01/15/154 9/persentase-penduduk-miskin-pada-september2018-sebesar-9-66-persen.html.

Ismail, I. dkk. (2016). Entrepreneurial Success Among Single Mothers: The Role of Motivation and Passion. Procedia Economics and Finance, 37: 121-128.

Setyaningsih, S. dkk. (2012). Women Empowerment trough Creative Industry: A Case Study. Procedia Economics and Finance, 4: 213222.

Victoria, I. dkk. (2019). Empowering Women Micro-Entrepreneurs in Emerging Economies: The Role of Information Communications Technology. Journal of Business Research, 99: 191-203. 